\title{
Soil Electrical conductivity as Affected by Biochar Under Summer Crops
}

\author{
Haq Nawaz*1, Hudood Ullah' ${ }^{2}$, Noor Ul Basar ${ }^{2}$, Farhan Ahmed ${ }^{1}$, Waseem Abbas ${ }^{1}$, Junaid Ahmed ${ }^{1}$ and Zahid \\ Mehmood $^{1}$
}

${ }^{1}$ Department of Agronomy, the University of Agriculture, Pakistan

${ }^{2}$ Department of Soil and Environmental Sciences, the University of Agriculture, Pakistan

Submission: September 09, 2018; Published: September 20, 2018

*Corresponding author: Haq Nawaz, Department of Agronomy, the University of Agriculture, Peshawar Pakistan, Tel: +923239712755;

Email: haqnawaz63@aup.edu.pk

\begin{abstract}
A field experiment was conducted to investigate the effect of biochar on soil electrical conductivity under summer crop at the research farm of the University of Agriculture, Peshawar during kharif, 2017. The experiment was performed in RCB design having four replicates. Different level of biochar $0,5,0$, and $10 \mathrm{t} \mathrm{ha}^{-1}$ was applied to field. Data on soil electrical conductivity was taken. The result shows all soil samples under different crops (Chickpea-maize, chickpea-mung, wheat-maize and wheat-mung) were nonsaline in nature. Mean electrical conductivity was maximum $\left(0.067 \mathrm{dSm}^{-1}\right)$ for treatment (T3) which had not received any biochar while remaining treatments has same electrical conductivity which is $0.066 \mathrm{dSm}^{-1}$. Furthermore mean electrical conductivity of soil under chickpea/maize and chickpea mung cropping system is 0.070 and $0.071 \mathrm{dSm}^{-1}$ respectively while soil under wheat-maize and wheat-mung cropping system has the EC of 0.061 and $0.064 \mathrm{dSm}{ }^{-1}$ respectively. These results suggested that Biochar should be use to lower the soil electrical conductivity. Further studies are needed to explore the results.
\end{abstract}

Keywords: Biochar; Soil Electrical Conductivity; Summer Crops

\section{Introduction}

Biochar is a solid fine-grained porous material obtained from the thermo-chemical conversion of plants biomass at relatively low temperature (350-6000C) in a low oxygen supply [1]. Soil physical properties are change by the addition of biochar contains carbon, Hydrogen, Oxygen, Nitrogen, Sulphur and Ash in sole amounts [2]. Biochar amendment [3]. The quantity which make biochar attractive as soil amendment is being highly porous [4]. Applying biochar as soil amendment can also enhance soil fertility and reduce carbon evolution [5]. Formation of biochar from biomass increases carbon stability and then applied to the soil. Similarly, it also reduces increased level of carbon dioxide in atmosphere. Biochar contains large quantity of carbon which is resistant to rapid degradation, so it sequesters carbon [6]. Biochar application improves soil properties like increased water holding capacity, enchanced CEC, and higher $\mathrm{pH}$, reduce nutrients leaching and provide nutrients to the soil [7]. Amending biochar to the soil increase crop yield. Applying biochar as soil amendment may improve microbial growth [8]. The net influence of biochar on the physical characteristics of the soil depend on the interaction of the biochar by way of the physio-chemical properties of the soil [9]. Amendment of biochar act as a conditioner which reduces the need of fertilizer, it holds the nutrients slowly for the later use of crop. As it also improves the water holding capacity and hence safeguarding crop against water stress, also lower the methane emission from paddy soil. While enhancing the yield of maize, biochar should be applied with companion of NPK.

Nitrogen is the most important nutrient required by plants for their higher growth which gives dark green color to the plant [10]. The yield multiplied at the proper $\mathrm{N}$ rate and effectively utilize by crop if applied top dressing method. It increases the plumpness of the grains and their protein content. In all plants nitrogen considerably influence the utilization of phosphorus and potassium. Phosphorus is the major nutrient needed by the plants in large quantity for greater yield. It concern primarily with preparative size increase. In most soil phosphorus is a yield reducing nutrient [11]. It is the 2 nd most crop limiting nutrient in most soil. Phosphorus is important for growth, utilization of sugar and starch, photosynthesis, nucleus formation and cell division. Similarly potassium is also a major nutrient needed by crops on large quantity. $\mathrm{K}$ increase protein content of crop, maintains turgor, reduce water loss, and protect plant against diseases as well as nematodes [12]. In Pakistan most of soil contain relatively greater amount of total $\mathrm{K}$, however only a small portion is in available form to the plants. Most of the soils have, $<150 \mathrm{mg} / \mathrm{kg}$ of exchangeable $\mathrm{K}$, which is considered a critical limit for soil K deficiency [13]. The cultivable land is a restricted resources and its extension is not possible, thus better 
crop production on sustainable basis is a great concern. This study was therefore proposed to evaluate the combined effect of biochar and NPK fertilizer on soil properties and maize crop at Peshawar valley.

Biochar has been used as a resistant organic matter by researchers and it has been used as the source of soil organic material [14]. The biochar applied to the soil showed similar effect as like the effect of organic matter [15]. Biochar is fine grained charcoal largely resistant to breakdown and high in organic carbon. It is produced from pyrolysis of plant and other organic waste food stock, Biochar application has received a growing interest as a sustainable technology to improve highly weathered or degraded soil Biochar can also improve the soil physical and chemical properties and enhance the action of soil biology, and it has been proved by researchers [16]. That biochar application increase fertility of soil and nutrients availability in plants. Biochar is an organic compound obtained by combusting plant and crop residues in a closed system under no oxygen supply [17]. Biochar is produced from products such as manures (FYM and poultry manures), crop residues, woods, trees residues and tree green waste using new pyrolytic technology [18]. Biochar usually has greater sorption capacity as compared to other organic matters [19]. The incorporation of biochar in soil decreases the loss of nutrients and thereby water resources. Furthermore, Biochar adsorbed organic contaminants in soil [20].

Phosphorus is one of the most important nutrients for higher yield in larger quantity [21] and controls mainly the reproductive growth of plant [22]. P is the second most crop-limiting nutrient in most soils. It is needed for growth, utilization of sugar and starch, photosynthesis, nucleus formation and cell division, fat and albumen formation. Energy from photosynthesis and the metabolism of carbohydrates is stored in phosphate compounds for later use in growth and reproduction [23]. Potassium (K) is an essential nutrient for plant growth and cannot be replaced by other elements. The function of potassium is associated with increased root growth and tolerance to drought, cellulose formation, enzyme activity, photosynthesis, transportation of sugar and starch. It also increases protein content of plants, maintain turgor, reduce water loss, and to protect plants against diseases and nematodes [24].

\section{Materials and Methods}

To evaluate the influence of biochar on soil electrical conductivity under summer crop, a field experiment was carried out at the research farm of The University of Agriculture, Peshawar during kharif season 2017. The experiment was laid out in a RCB design having four replications. The size of the treatment plot was kept $3 \times 3.5 \mathrm{~m}^{2}$. The levels of biochar applied were $\left(0,5,10 \mathrm{t} \mathrm{ha}^{-1}\right)$. Basal dose of NPK was applied to the crop (Table 1). Mungbean and maize crop was sown after the harvesting of chickpea and wheat from the field. Biochar were applied before sowing and thoroughly mixed in to the soil.
All recommended cultural practices were followed during the growing period.

Table 1.

\begin{tabular}{|c|c|}
\hline Treatment & Biochar $\left(\mathbf{t ~ h a}^{-\mathbf{1}}\right)$ \\
\hline $\mathrm{T} 1$ & 0 \\
\hline $\mathrm{T} 2$ & 5 \\
\hline $\mathrm{T} 3$ & 0 \\
\hline $\mathrm{T} 4$ & 10 \\
\hline
\end{tabular}

\section{Soil Sampling}

Soil samples from each subplot in each cropping system (chickpea-maize, chickpea-mung, wheat-maize and wheatmung) were taken at depth of 0-15 cm. Samples were packed in plastics bags and were properly labeled. Samples were transported to the lab of department of Soil and Environmental Sciences, The University of Agriculture, Peshawar. Samples were air dried at room and then placed in oven for complete drying. After complete drying samples were grounded and sieved through sieve of $2 \mathrm{~mm}$ and collected in plastic bags properly labeled. The samples were further processed for chemical analysis.

\section{Chemical Analysis}

Electrical Conductivity: Ten-gram soil sample was taken in plastic bottle and $50 \mathrm{ml}$ of distilled water was added to make 1:5 soil water suspensions. The suspension was shaken for 30 minutes on horizontal shaker. The EC of the soil samples was measured by the EC meter (Table 2) [25-28].

Table 2. Classification of soil samples based on Electrical Conductivity.

\begin{tabular}{|c|c|}
\hline Nature of Soil & Range $(\mathbf{d S} / \mathbf{m})$ \\
\hline Normal & $<4$ \\
\hline Saline & $\geq 4$ \\
\hline Sodic & $<4$ \\
\hline Saline sodic & $\geq 4$ \\
\hline
\end{tabular}

\section{Results}

To assess the influence of biochar on soil electrical conductivity under summer crop a field experiment was conducted at agriculture research farm Malakandir, The University of Agriculture, Peshawar during summer 2017. Experiment was laid out in Randomized Complete Block design having four replications. Biochar was applied at 0, 5, 0 and 10 $\mathrm{t} \mathrm{ha}^{-1}$. All the required biochar was applied before the sowing of crop. Mungbean and maize crop was sown with row-row distance of $75 \mathrm{~cm}$, after the harvest of chickpea and wheat crop from the following fields. After harvesting of crop, soil samples were analyzed for electrical conductivity.

\section{Soil Electrical Conductivity ( $\mathrm{dS} \mathrm{m}^{-1}$ )}

More recently electrical conductivity has come to use for measuring the amount of total salt in solution. It is determined by the electrical conductivity meter. Electrical conductivity 
increases with increasing salt concentration, these soils have no salinity problem because of high rainfall; salts are generally carried downward by rainwater into ground water and ultimately reach to ocean, streams and rivers.

Data regarding electrical conductivity is presented in Table 3. The data reveled that soil EC in almost all samples indicate that amount of total soluble salts are not too much higher. All the samples are non-saline. Furthermore the data shows that Table 3. Classification of soil samples based on Electrical Conductivity. mean electrical conductivity was maximum $\left(0.067 \mathrm{dSm}^{-1}\right)$ for treatment (T3) which had not received any biochar while remaining treatments has same electrical conductivity which is $0.066 \mathrm{dSm}^{-1}$. Furthermore, mean electrical conductivity of soil under chickpea/maize and chickpea mung cropping system is 0.070 and $0.071 \mathrm{dSm}-1$ respectively while soil under wheatmaize and wheat-mung cropping system has the EC of 0.061 and $0.064 \mathrm{dSm}^{-1}$ respectively.

\begin{tabular}{|c|c|c|c|c|c|}
\hline Biochar (t/ha) & Chickpea/Maize & Wheat/Maize & Chickpea/Mung & Wheat/Mung & Mean \\
\hline $\mathrm{T} 1=0$ & 0.070 & 0.062 & 0.071 & 0.061 & 0.066 \\
\hline $\mathrm{T} 2=5$ & 0.071 & 0.062 & 0.069 & 0.063 & 0.066 \\
\hline $\mathrm{T} 3=0$ & 0.070 & 0.062 & 0.071 & 0.064 & 0.067 \\
\hline $\mathrm{T} 4=10$ & 0.070 & 0.061 & 0.072 & 0.063 & 0.066 \\
\hline Mean & 0.070 & 0.061 & 0.071 & 0.063 & \\
\hline
\end{tabular}

\section{Conclusion and Recommendations}

The following conclusions could be drawn from the present research work.

a) All the soil samples under all summer crops (Chickpeamaize, chickpea-mung, wheat-maize and wheat-mung) were non-saline in nature having very low electrical conductivity.

b) It could be recommended from obtained conclusions that.

c) Biochar should be use to lower the soil electrical conductivity.

d) Further studies is needed to explore the results.

\section{References}

1. Amonette J, S Joseph (2009) Characteristics of biochar Micro-chemical properties. In biochar for environmental management: Science and Technology (J Lehmann and S Joseph edu) Earthscan London, p. 33-52.

2. Arif M, A Ali, M Umair, F Munsif, K Ali, et al. (2012) Effect of biochar FYM and mineral nitrogen alone and in combination on yield and yield components of maize. Sarhad J Agric 28(2): 191-195.

3. Bajawa MI, F Rehman (1996) Soil and fertilizer Potassium. soil science E Bashir, R Bantle, pp. 317-341.

4. Carter S, S Shackley, S Sohi, TB Suy (2013) The impact of biochar application on soil properties and plant growth of lettuce (Lactuca sativa) and cabbage (brassica chinensis). Agronomy 3: 404-418.

5. Chen ML, XL Jiang, BY Zoov, ZY Zheri (1994) Mathematical models and best combination of high yield cultivation technique for repeseed variety Zhenyouyoum. Acta Agriculture Zhejiangensi 6: 22-26.

6. Cornelissen G, V Martinsen, V Alling, GD Breedveld, DW Rutherford, et al. (2010) Bioenergy development issues and impacts for poverty and natural resource management. World Bank Publication.

7. FAO (2007) Utilization of tropical nutrition paper 4711, FAO, Rome.

8. Glaser B, J Lehmann, W Zech (2002) Ameliorating physical and chemical properties and plant growth of pot growth lettuce (lactuca sativa) and cabbage (brassica chinensis). Agronomy 3: 404-418

9. Hale A, Obia, J Mulder (2013) Biochar effect on maize yield and soil characteristics in five conservation farming sites in Zambia. Agronomy 3(2): 256-274.
10. Husssain N, AZ Khan, H Akbar, NG Bangash, ZH Khan, et al. (2007) Response of maize varieties to phosphorus and potassium levels. Sarhad J Agric 23 (4): 882-888.

11. Ihsan H, IH Khalil, H Rehman, M Iqbal (2005) Genotypic variability for morohological traits among exotic maize hybrids. Sarhad J Agric 21(4): 599-602.

12. Imran M, M Arif, S Ali, S Ahmad, Majidullah, et al. (2014) Integration of biochar with organic and in organic sources of phosphorus for improving maize productivity. Journal of Envionment and Earth Science 4(11): 1-6

13. John A, Fagbenro O, Suarau Oshunsanya, A Bolarinwa, Oyeleye (2015) Effects of Gliricidia Biochar and Inorganic Fertilizer on Moringa plant Grpwn in an Oxisol. Communications in soil science and plant analysis 46: 619-626.

14. Kannan RL, M Dhivya, D Binaya, RL Krishna, SK Kumarn (2013) Effect of integrated nutrient management on soil fertility and productivity in maize. Bulletin of Environment, Pharmacology and Life Sciences 2 (8): $61-67$

15. Khaliq T, T Mehmood, J Kamal, A Masood (2004) Effectiveness of farmyard manure, poultry manure and nitrogen for corn productivity. International Journal of Agriculture and Biology 6(2): 260-263.

16. Lehmann J, S Joseph (2009) Biochar for environmental management. Earthscan Publisher Ltd pp. 658-978.

17. Malival PL (2001) Agronomy at a glance. Agrotech publishing academy, Udaipur pp. 78-80.

18. Masek 0 (2009) Biochar production technologies.

19. Masood T, R Gul, F Munsif, F Jalal, Z Hussain, et al. (2011) Effect of different phosphorus levels on the yield and yield components of maize. Sarhad Journal of Agriculture 27(2): 167-170.

20. Memon SQ, N Mirjat, AQ Mughal, N Amjad (2012) Effects of different tillage and fertilizer treatment on growth and yield components of maize. Pak J Agri Agril Engg Vet Sci 28(2): 160-176.

21. MNFSR (2013-2014) Ministry of National Food Security and Research. Govt of Pakistan Economic wing, Islamabad.

22. Pandian KP, Subramaniayan P, Gnasekaran, S Chitraputhirapillai (2016) Effect of biochar amendment on soil physical, chemical and biological properties and groundnut yield in rain fed Alfisol of semiarid tropics. Archives of Argon and Soil Sci 62(9): 1293-1310.

23. Pietikainen J, O Kiikkila, H Fritze (2000) Charcoal as a habitat for microbes and its effect on the microbial community of the underlying humus. Oikos International 89: 231-242. 
24. Shah Z, MT Jan, Z Shah, M Afzal (2007) Response of maize to integrated use of compost and urea fertilizer. Sarhad J Agric 23(3): 126-132.

25. Venterea RT, JM Baker (2008) Effects of soil physical nonuniformity on chamber-based gas flux estimites. Soil Science Society of America 72 (5): 1410-1417.

26. Widowati, Asnah (2014) Biochar can enhance potassium fertilization efficiency and economic feasibility of maize cultivation. Journal of Agriculture Science 6(2): 24-32.

This work is licensed under Creative Commons Attribution 4.0 License

DOI: 10.19080/IJESNR.2018.14.555887
27.Zheng A, R Biana, G Pana, L Cuia, Q Hussaina, et al. (2012) Effects of biochar amendment on soil quality, crop yield and greenhouse gas emission in a chinese rice paddy: A field study of 2 consecutive rice growing cycles Field Crop Research 127: 153-160.

28. Zhu Q X Peng, T Huang (2015) Contrasted effects of biochar on maize growth and $\mathrm{N}$ use efficiency depending on soil condititions. INT Agrophys 29: 257-266.

Your next submission with Juniper Publishers will reach you the below assets

- Quality Editorial service

- Swift Peer Review

- Reprints availability

- E-prints Service

- Manuscript Podcast for convenient understanding

- Global attainment for your research

- Manuscript accessibility in different formats (Pdf, E-pub, Full Text, Audio)

- Unceasing customer service

Track the below URL for one-step submission https://juniperpublishers.com/online-submission.php 